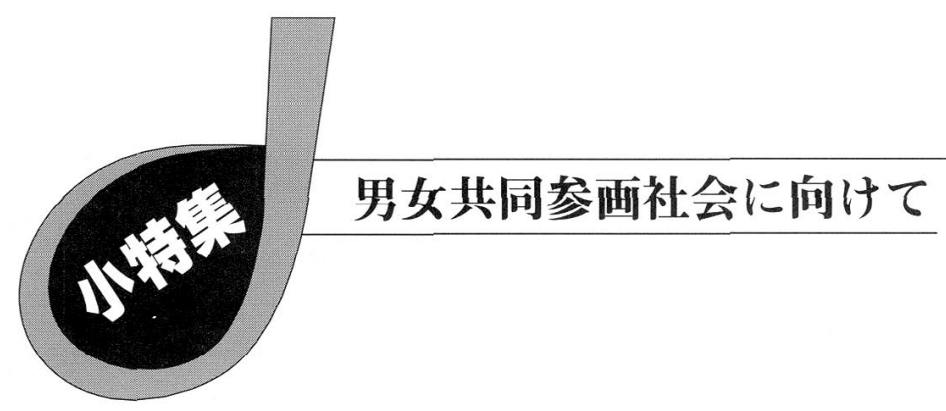

\title{
東北大学における男女共同参画推進の 取り組み
}

米 永一 郎*

男女共同参画社会を実現するために先端研究とその教育実 践を本分とする機関として大学の役割は大きい，東北大学で は全学を挙げて, 両性がともに輝ける男女共同参画型大学を 目指した積極的な取り組久を展開している。ここでは，その 司令塔となる東北大学男女共同参画委員会のこれまでの活動 の一端を紹介する．ここで報告する多くは東北大学男女共同 参画委員会のホームページ (http://www.bureau.tohoku.ac. jp/danjyo/)にあるので, 是非ご覧頂きたい.

\section{1. 東北大学における男女共同参画の歴史}

東北大学は我が国0)大学ではじめて女子学生を入学させた 歴史がある。東北帝国大学理科大学は初代総長澤柳政太郎の 時, 高等学恔以外の高等師範, 高等工業の卒業生, および中 等教員免許試験合格者に受験資格の桩大を決定した。その大 学の門戸解放は女性に対しても適用され，4名が受験し， 1913 年 (大正 2 年) 8 月 16 日, 牧田らく(数学), 黒田チ力 (化 学), 丹下ウメ(化学)の 3 名が合格した. 彼女らの受験·入 学資格は中等教員免許状所有者としてであり, 実際東京女子 高等師範学校 (現 お茶の水女子大学), 日本女子大学校(現 二本女子大学) で助教授であった. 文部省からは「女子を入 学させるとは何事か」という再考を促す強い指導があった が(1), 2 代総長北條時敬のもと決定が貫かれた(図 1). 男子 学生からも強硬な反対があった。そのような世襲監視・注目 の中で, 途中病気で休学した丹下ウメを除き, 牧田らく, 黒田チ力は 3 年後理学士となった. 黒田チ力は天然色素の分 子構造を研究し植物学の保井コノに続き, 日本で 2 番目の 女性理学博士となった. 第二次世界大戦後新学制のお茶の水 女子大学に抢いて初の女性教授上なり, 結晶化学分野に貢献 した. 丹下ウメは卒業後, 米国ショョン・ホプキンス大学に留

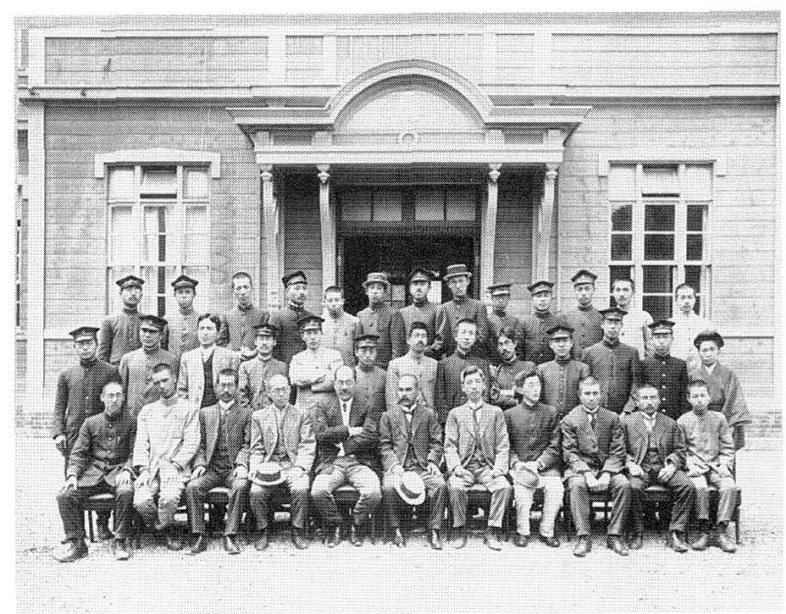

図 1 1914年(大正 3 年) 6 月理科大学化学科第 1 回卒 業記念 (黒田于力 : 2 列目右端) (東北大学史料館 より).

学し, ビタミンCを中心に栄養化学の研究を進めて農学博 士号を取得し, 日本の家政学を発展させた。数学の牧田らく は孤高の日本画家 金山平三と結婚し妻として平三を支える 人生を選んだが，数学への思いはつきず，「Linkageに関す 万著作の目録」などの文献目録を完成させた。黑田チカと丹 下ウメが生涯独身で研究を続け, 一方で牧田らくが家庭を選 んだことは，今回のアンケート(*本特集 : 男女共同参画学協 会連絡会アンケート結果速報・御手洗容子) で年配の女性研 究者に見られた独身であることの特徵と相通じており, また 現在でも女性研究者・科学者が直面する難しい課題である. な掠，黒田チカと牧田らくに関しては都河明子らの著書に詳 Lい(2).

\footnotetext{
* 東北大学助教授 ; 金属材料研究所 ( $9980-8577$ 仙台市青葉区片平2-1-1)

Activities of the Tohoku University for Realizing a Gender-equal Society; Ichiro Yonenaga(Institute for Materials Research, Tohoku University, Sendai)

Keywords: gender equality, activities of Tohoku university for gender equality, sawayanagi encouragement Prize, Tohoku university declaration 2004 年 9 月 6 日受理
} 


\section{2. 東北大学男女共同参画委員会とその活動経過}

東北大学において全学レベルでの委員会で男从共同参画に ついて議論が始まったのは1998年度の「東北大学の在り方 に関する検討委員会」の「研究教育等改革委員会」において であり，これは1999年 6 月制定の「男女共同参画社会基本 法」より約 1 年早い. 2000 年 5 月の国立大学協会の男女共 同参画に関するワーキング・グループからの報告書「国立大 学に㧍ける男女共同参画を推進するために」(2010年むでに 女性教官比率を $20 \%$ にする数值目標) を受け, 委員会の付託 検討事項として「男女共同参画」に関する本格的な取り組み が始まった。そして，2001年 4 月に東北大学男女共同参画 委員会が馬渡尚憲副総長 (現宮城大学学長) を委員長として設 置され，今日に至る。

現在, 東北大学の男女共同参画委員会は鈴木厚人東北大学 総長補佐を委員長, 过村み上子法学研究科教授を副委員長上 し, 理事, 各部局代表, 留学生センターと学生相談所の代 表, 事務方から総務部長を委員とした総勢24名で構成され ている. 委員会の構成において, 共同参画の観点で男女いず れか一方の委員の数が, 委員の総数の 10 分の 3 未満になら ないよう留意することが規定されている，委員の任期は 2 年である。

委員会の所掌事項は

1. 男女共同参画の現状の自己評価およびその公表に関す る事項

2. 男女共同参画の推進のために必要な啓発活動に関する 事項

3. その他男女共同参画に関する重要事項

と規定されている。また後述する 2002 年の東北大学宣言に 謳われている。 その任務に従い, 委員は実態調査, 広報活 動, 相談空口等, 両立支援 (保育所関係), 奨励制度, 報告書 作成の 6 ワーキンググループの 2 つに属して活動している.

実態調査 WG は学内に打㭷女共同参画の現状の自己 評価と啓発活動のための方針策定の参考として，2001年部 局長および教職員, 2002年非常勤職員, 2003年学生・院生 を対象とした男女共同参画に関する意識調査を行った(学 生・院生の意識調査結果については後述する.).さらに職員

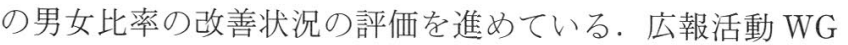
はシンポジムの開催と委員会活動のホームページへの掲載 を担当している。相談密口等 WG は, 男女共同参画に関す る職種や昇進に関する差別的取り扱いなどの不利益の救済を 目的に, 学生相談空口抢よびセクシャルハラスメント相談空 口と連携して相談を受け付けている。両立支援WG は学内 保育所の設置に向けた検討を進め川内地区での設置とその運 営形態の提言を行っている. 奖励制度 WG は後述する東北 大学独自の男女共同参画奨励賞 (澤柳賞) の選考を任務とす る. 報告書 WG は委員会活動の総括とともに，中期計画や ジェンダー教育の推進に関する提言を行っている.

\section{3. 東北大学宣言}

男女共同参画推進のための東北大学宣言は2002年 9 月 28 日の第 1 回東北大学男女共同参画シンポジウムにおいて 阿部博之総長 (当時) によって, 男女共同参画推進のため東北 大学の全構成員の共通目標として, 以下の方針が発表された.

1. 男女共同参画奨励賞 (澤柳賞)の創設, ジェンダー学の 普及

2. 男女格差是正, 方針決定機関での推進, 研究 - 労働環 境の改善，育児介護のにお打る性別役割分業の改善々 両立支援体制の確立

3. 不服申立・救済制度の整備

そして，「大学に打ける男女共同参画型の教育・研究活動の 実践こそが21世紀の重要課題であることを認識し，東北大 学が全国の大学の前駆となるべく, 率先して男女共同参画社 会の実現のために積極的な取り組みを進めること」ことを宣 言している. (http://www.bureau.tohoku.ac.jp/danjyo/2-32/4.htm)

\section{4. 東北大学男女共同参画シンポジウム}

第 1 回シンポジウムは 2002 年 9 月 28 日, 仙台国際センタ 一に抒いて「学問・教育と男女共同参画」を主題として開催 された。馬渡尚憲委員長の委員会活動報告に続き, 基調講演 として, 原ひろ子放送大学教授 (お茶の水女子大学名誉教 授）による「学術の世界における男女共同参画」と，小舘香 椎子日本女子大学教授による「理工系分野における男女共同 参画の推進について」が行われた，それに引き続き，学内代 表による「東北大学におりる男女共同参画の現状と課題」と 題するパネルディスカッションがあり，活発な意見発表と䚯 論がなされた（図 2)。（前金属学会会長である井口泰孝教授 も工学系の代表としてパネラーに加わった)．そして，阿部 博之総長により「男女共同参画推進のための東北大学宣言」 がなされた。その参加人数は約 470 名であり, 東北大学の教 職員や学生だけでなく, 一般市民の方々や，他大学，内閣 府，自治体関係者加も多くの参加を得た。

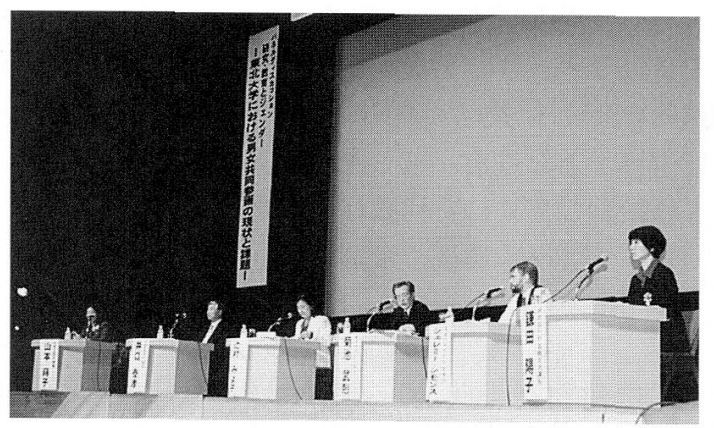

図 2 第 1 回男女共同参画シンポジウムでの東北大学 の教職員によるパネルディスカッション ${ }^{(3)}$. 


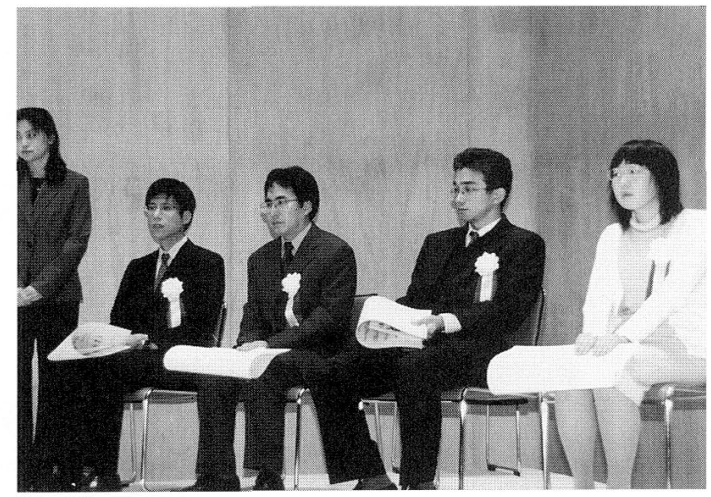

図 3 第 1 回澤柳賞授賞式 ${ }^{(4)}$.

第 2 回シンポシウムは2003年11月26日, 東北大学川内地 区，マルチメディア教育研究棟ホールに扔いて「性差とは何 か？ヒトと人のあいだ」を主題として開催された。このシ ンポジウムでは前年創設された東北大学男女共同参画奨励賞 (澤柳賞)の第 1 回目の授賞者 4 名(後述)の授賞式とその受 賞講演に続き，長谷川眞理子早稲田大学教授による「性差と 進化の謎」と題する特別講演が行われた。東北大学の教職員 や学生を中心に約 160 名が参加した.

\section{5. 東北大学男女共同参画奨励賞 (澤柳賞)}

2002年 9 月に創設された東北大学男女共同参画奨励賞(澤 柳賞)はリサーチ部門(ジェンダー学等の男女共同参画に関連 する研究)，エンパワメント部門(男女共同参画に関する現在 進行中の社会的・教育的活動), プロシェクト部門(上記 2 部門に関して今後成果が期待される研究・活動企画提案) か らなる。そして，各受賞者はその年の男女共同参画シンポジ ウムでの)成果の発表(プロジェクト部門は翌年ないし翌々年 のシンポジウム)が義務づけられている。この賞の特徵は, 男女共同参画の推進を目指した個人やグループの研究や活動 を奨励するもので，猿橋賞のような女性研究者による研究活 動・成果を対象としたものではないことである。その第 1 回奨励賞 (2003年度) は 4 月に公募が開始され，6月末の締切 りで18件の応募があった。そして、リサーチ部門(田中重人 文学研究科講師・階層論の枠組风に上万性別格差と平等政策 の研究), エンパワメント部門(星陵地区病児保育施設運営委 員会・星陵地区に抢ける病览保育施設の運営について), プ ロジェクト部門 (小川佳万教育学研究科助教授・高大連携に よる女子高校生の理数科教育サポート計画) が授与された。 さらにプロジェクト部門の特別賞に経済学部 3 年生の勝又 梨穂子氏が選ばれた(図 3).2004年度第 2 回奨励賞も 7 月末 の締切りで10件の応募があり，現在審査中である。

\section{6. 東北大学学内保育所の設置}

現状では女性研究者の育児に関する負担は大きく，仕事と 育児の両立のために所属場所の近くでの保育施設を利用でき
ることが要望されている．東北大学では多くの学部・施設が ある川内・青葉山地区が町の中心からやや離れているが保育 施設はなく，そこで川内地区に保育所を設置することが提言 された。その提言では保育所はせんだい保育室 B 型と呼ば れる，無認可保育所の中で国の基準には足りないが，仙台市 が独自に助成する準認可的保育園とすること，上地と建物を 大学が準備し, 運営は民間に委託すること，18名程度の常 時保育を予定し，个後 8 時屯での延長保育抢よび 12 名程度 の一時預かりを予定する案が示された。そして，2004年度 教職員・院生を対象に利用見込みに関するアンケート調査が 行われている。

\section{7. 学生・院生の男女共同参画に関する意識調査}

東北大学ではこれまで全構成員に対する男女共同参画に関 する意識調査を進めてきたが，ここでは次の研究者世代であ る学生・院生を対象として2003年10-11月に実施した調査結 果の一部を紹介する。なお，結果はそれぞれ異なる背景を有 する文系・理系を全て含むことを了解頂きたい。

アンケート（図 4)に対して，全学生・院生18000名のうち 約4000名から回答があった。まず，男女共同参画という言 葉について，回答者の53\%が「聞いたことがある」と答え た。これは以前に実施した教職員抢よび非常勤職員対象のア ンケート結果(それぞれ60\%，68\%)に較べ，高くない。女 性の方が男性より認識度は高い。

大学入学以前0男女差別について，「しばしばあった」, 「あった」ないし「感じた」と回答したものは17\%あった。 その内容として，从性は「進路指導」における助言の少な さ，大学進学に対する周囲の反対，「家庭生活」での“らし さ”の強要，役割分担を挙げている．例えば，「弟は進路を よく考えるように言わ枕が，女の子は結局家庭に入るのだ から好きなことを大学で学んでよいと言われた」,「女子学生 対象の推薦入試があるという名目で志望外の大学を進められ 東北大の推薦に他の男子学生をあてがうことをされそうにな った」. 男性では「学校生活」でのやはり役割分担と女性優 遇差別老述べている。大学内での男女差別について，「しば しばあった」「あった」ないし「感じた」との回答が $16 \%$ あり，授業，クラブ活動，アルバイト紹介について具体的理 由を挙げている。研究室での差別について，「しばしばあっ た」「「あた」ないし「感じた」と回答したものは $6 \%$ だあ り, 研究室内での役割分担 (受付, 力仕事など), 差別的発言 (女たから, 男だったらなど), 研究指導や八ラスメント(女 性への優しい指導と男性への厳し(指導), 女性の研究室へ の配属人数制限と女性への研究指導の甘さ, 更衣室の不備な どが挙げられた。例えば，「女はどうせ〜だからという意識 をもって接している」,「テーマの決定, 進路の決定など, 将 来性がないものとして扱われる」，「男子学生は先輩からの扱 われ方が何故か過酷」,「男, 女ではなく, 一人の生徒·学生 として見て欲しい」が記されている.

進路決定において男女差別の有無や性別の考慮について， 


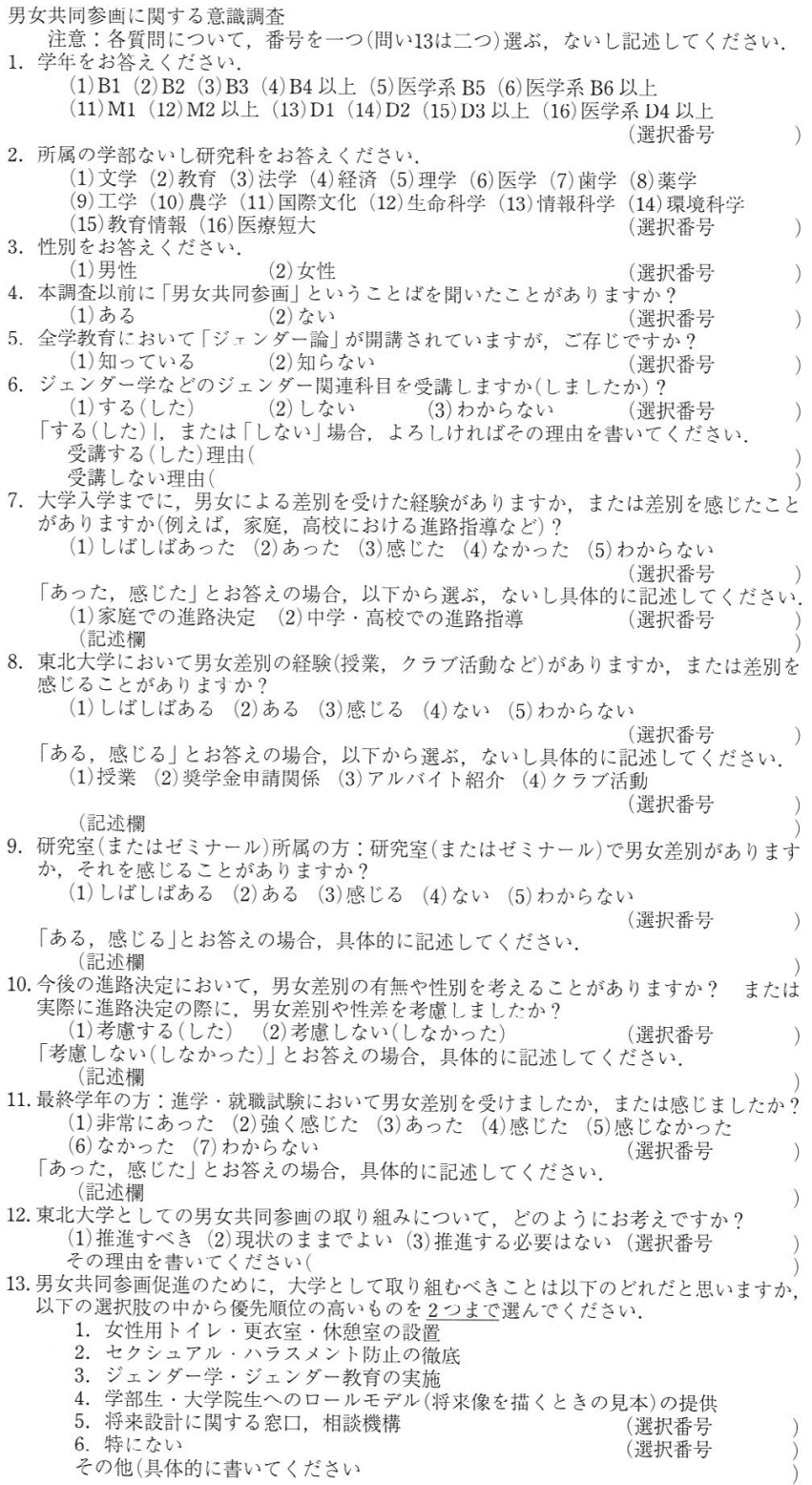

図 4 2003年に実施された学生・院生を対象としたア ンケート.

「考慮する」ないし「考慮した」と回答した男性は約30\%, 女性は約70\%であった。考慮しない理由は問題を意識せ ず，進路決定に男女差別はない，理系には男女差別はない， 自分の希望を優先，男性に不利益はないなどがあったが，一 方「男女差別の有るところでは自分のやりたいことをのびの びとやることができないと思うので考虑し, 男女差別のない ところに進路を決めたい」も記されていた. 進学・就職試験 での男女差別の経験について，「非常にあった」，「強く感じ

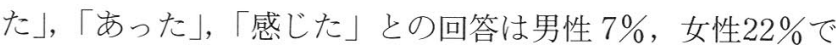
あった。記述された事例は「求人情報・応募」,「会社訪問・ 説明」, 「面接を含む試験」,「最終結果」，「その他」に分類さ れる(図 5)。具体的には，「“結婚したら仕事やめますか”, “从はすぐやめるから(あてにならない)”と面接で言われ た」，「女子は途中までは選考に残れるが，最終的に採用とな

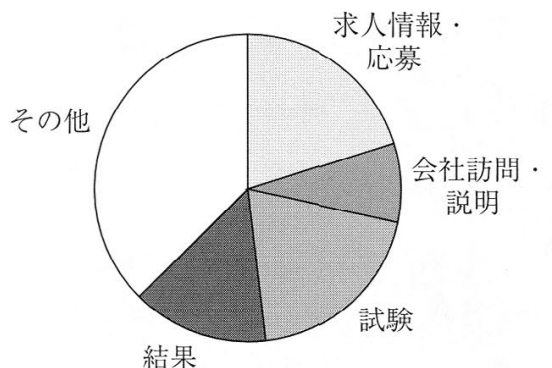

図 5 就職試験において「男女差別があった・感じた」 場合の具体的理由.

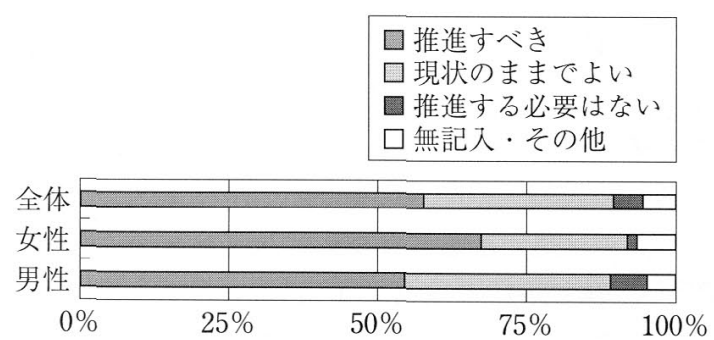

図 6 質問「東北大学は男女共同参画を推進すべきか」 に関する回答.

るのはごく少数」,「男女共同参画のせいで女が優遇されてい る」などがある。

東北大学は男女共同参画を推進すべきかとの質問に対し て，「推進すべきである」との回答は58\%（男性55\%，女性 $67 \%$ )，「現状の屯までよい」は32\%(男性35\%，女性25\%)， 「推進する必要はない」は5\%(男性 6\%, 女性 2\%) であった （図 6). 学年別では，推進すべきであるとの回答は男性では ほぼ一定であるが，女性では高学年になるほどが増加する。 理科采に所属する男性では文科系に較べると, 推進すべきで あるとの回答が少なく, 現状のままでよい, ないし推進する 必要はないとの回答が多かった．「推進すべきである」とす る理由は「男女共同参画に賛同する」,「男女差別の解消」, 「東北大学の使命」等に分類される。具体的には「性別で何 かを諦めることをしてほしくないから」,「男女差別を感じな かったというのは“ない”と違いすす。なれているからそれ を差別ではないと思う人もいるでしょう」, 「若いうち意識を 養わなくては，身につかないから」などがある。「現状のま までよい」とする理由は「男女差別の問題は存在しない」, 「逆差別を招く」,「大学の取り組むべき課題ではない」,「や りたい人がやればよい」等に分類される．「推進する必要は ない」とする理由は「男女差別はない」，「男女差別・区別は 当然」「男女共同参画を否定」等に分類される。具体的には 「現状でも女性は十分に能力を発揮しているため」，「女に学 問の必要なし」，「いちいち気にするなかれ，かっこつける な」,「そのように言うこと自体が男女差別につながるし，男 性よりも女性のあまえによって消えることはないと思うか ら」などがあった。（詳細は平成15年(2003年)度男女共同参 
画委員会報告書にあり，PDFファイルとしてもダウンロー ドできる)(4).

\section{8. 金属材料研究所での活動}

2002年 7 月部局毎に男女共同参画委員会ないし WG が結 成され，部局単位での個々の実状に即したセミナーやアンケ 一下調査等の活動が展開されている. 金属材料研究所(井上 明久所長)に打いても, 研究部, 技術部, 事務部の代表から なるワーキンググループが作られた，その活動としては， 2003年 5 月 30 日金属材料研究所の所内講演会での東芝・渡 辺美代子氏による「応用物理学会男女共同参画アンケート報 告と企業の取り組み」の特別講演，「女性が仕事を続けるに は女性先輩や仲間の話を聞くのが一番」を合い言葉に所属す る女性職員 (教官·技官) ·学生のネットワークの立ち上げ, 女性教官・技官々所属の男女学生・院生を対象にしたアンケ 一ト調査, トイレや更衣室等の実際に利用する立場からの点 検である、実施したアンケート調査の中では材料科学系とし ての金属材料研究所に就職した理由ないし教育研究機関とし て選んだ理由と各個人が感じられている現在の研究・教育に 関する達成度・満足度等を伺ったが，その中で女性研究者か らはこれからも研究を続けていくために「配偶者や職場の理 解」，「育児休暇や育児施設の充実」，「相談空口・先輩」等が 必要であるとの意見が寄せられた。金属材料研究所男女共同 参画WGの男女共同参画に関するアンケート調査結果の報 告 $(2004$ 年 2 月)を参照されたい.

\section{9. 今後の展 開}

これまで男女共同参画社会の実現に向けた東北大学の先駆 的活動を紹介した，その活動注目され，マスコミを通じて 多々発表され, また内閣府男从共同参画会議基本問題専門調
查会報告書「女性のチャレンジ支援策について」に扔いても 取り上げられている. また, 東北大学は打茶の水女子大学上 ともに21世紀 COE プログラム(社会科学)において「男女共 同参画社会の法と政策—ジェンダー法・政策センター」とし てジェンダー研究の拠点である(リーダー：辻村みよ子法学 研究科教授)，このように大きな成果を上げつつあるが，尚 課題も多く, 特に全学の女性教官比率は助手を含め6.7\%, 助手を除くと $4.3 \%$ で, 国大協の数值目標にはほど遠い。さ らに, 教職員の研究 ·労動環境の改善, 育児·介護休昵等の 取得に関しても課題が残されている。ここで, アンケートで 見られた結果として, 男女共同参画を認識する学生・院生ほ ぞ, また, ジェンダー学等を受講した学生・院牛ほど, 男女 共同参画を推進すべきであると考える割合が高く, 従って, 男女共同参画の推進に向けてその広報・啓発活動が重要であ ることを示している。

\section{文献}

（1）東北大学史料館： http://www.archives.tohoku.ac.jp/index. htm

（2）都河明子, 嘉ノ海暁子：拓く一日本女性科学者の軌跡一, ド メ久出版，(1996).

（3）大隅典子：まなびの杜, No. 22 (2002年 Winter), p. 3.

(4) 平成15年度東北大学男女共同参画委員会報告書.

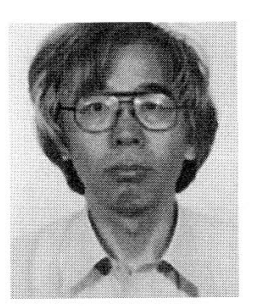

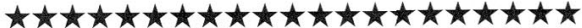
米永一郎

1980年 東北大学大学院工学研究科単位取得退学 1980年 東北大学金属材料研究所助手 1997年 東北大学金属材料研究所助教授 専門分野：欠陷構造·物性制御，混晶育成

$\mathrm{Si}, \mathrm{GaN}$ 等種々の半導体に抢ける転位の構造と特性を マルチスケールで研究中, 転位・不純物との反応によ る物性制御を進めている。 また, $\mathrm{SiGe}$ 等の混晶半導 体の創成とその物吽解明を行っている. 